\title{
Parallels between the civilian separate patrimony, real subrogation and the idea of property in a trust fund.
}

(Draft only, please do not cite)

Table of contents

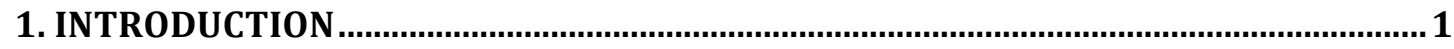

2. THE CONCEPT OF A SEPARATE PATRIMONY.........................................................

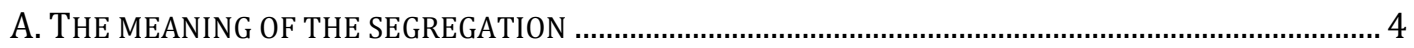

(a) Protection of separate patrimonies from otherwise enforceable claims...................... 5

(b) Liability for debts incurred with respect to separate patrimonies................................. 7

B. EXCHANGEABILITY OF THE ASSETS AS AN ELEMENT OF THE SEPARATE PATRIMONY ........................ 8

C. TYPES OF SEPARATE PATRIMONIES ........................................................................................... 11

3. REAL SUBROGATION AS A MECHANISM FOR ASSET EXCHANGEABILITY ............. 12

A. TWO TYPES OF REAL SUBROGATION................................................................................... 14

(a) Real subrogation within separate funds (in universalibus) ........................................ 14

(b) Real subrogation outside of separate funds (in singularibus).....................................16

B. NATURE OF THE SUBSTITUTION: OLD OR NEW RIGHT TO THE NEW ASSET? .................................. 17

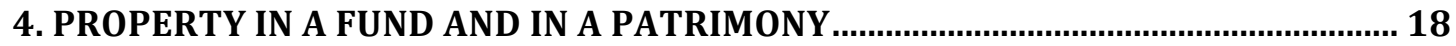

A. PROPERTY IN A PATRIMONY AS A COLLECTION OF ASSETS ……………...................................... 18

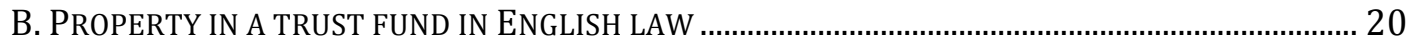

5. CONVERGENCE OF THE TRUST FUND AND SEPARATE PATRIMONY ....................... 23

A. AUTHORISED DIPOSITIONS: EXERCISE OF TRUSTEE'S POWERS AND REAL SUBROGATION

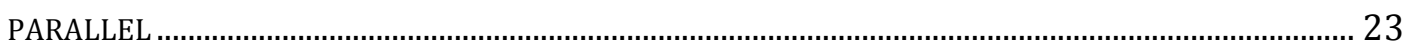

B. UNAUTHORISED DISPOSITIONS BY THE TRUSTEE ………....................................................... 25

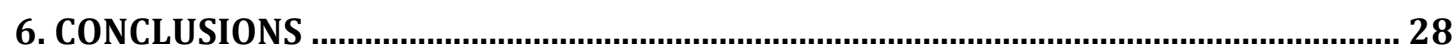

\section{Introduction}

One of the essential characteristics of the common law ${ }^{1}$ trust is that the trust property constitutes a segregated fund. ${ }^{2}$ It has been argued that the existence of a separate trust fund in common law helps to explain why a trust does not fail for want of a trustee, and crucially, why the creditors of the trustee have no claim on it. $^{3}$ The emphasis of the importance of a separate fund coupled with the expansiveness of trusts in non-common law jurisdictions has inevitably lead to a

\footnotetext{
- Magda Raczynska, University of East Anglia. I would like to thank Dr Duncan Sheehan and Prof Mathias Siems for their helpful comments. I am also grateful to Mr Ben McFarlane for his comments at the conference. All errors remain mine.

1 "Common law" is used here as the obverse of "civil law", rather than "Equity".

${ }^{2}$ DWM Waters, MR Gillen and LD Smith, Waters' Law of Trusts in Canada (Student edn, 3rd edn Thomson 2005) 9;

${ }^{3}$ G Gretton, 'Trusts without Equity' (2000) 49 ICLQ 599, 614.
} 
quest for functional equivalents of the trust fund within the civilian taxonomy. The concept of a separate patrimony transpired as a suitable candidate in civil jurisdictions to mirror the operation of a common law trust fund. Separate patrimonies have been known since Roman times (peculium) and are also present in modern civil law jurisdictions: for instance, the French patrimoine d'affectation and the German Sondervermögen. ${ }^{4}$ Professor Lawson commented that "a Sondervermögen can easily be created by means of a trust" ${ }^{5}$ but the question considered here is different: can a trust be created by a Sondervermögen? The separate patrimony has become the basis of the civilian versions of the trust in France ${ }^{6}$ and Lichtenstein ${ }^{7}$ and the Hague Convention on the Recognition of Trusts in its Article 2 refers to trust assets as constituting a "separate fund", which Professor George Gretton equates with a "special patrimony". 8

Immunity from execution of claims of the trustee's creditors is clearly a necessary but not a sufficient condition to construe a functional equivalent of a common law trust fund in civil law. It is important that new assets acquired with the exchange value of the assets within the fund will be protected against the creditors' claims, an effect to be ensured by real subrogation. ${ }^{9}$ Although it is debatable to what extent real subrogation is inherent in the notion of a separate patrimony, ${ }^{10}$ both separate patrimony and real subrogation have been included in the list of "core elements" which a civilian construct would need to display in order to structurally and functionally match the common law trust. ${ }^{11}$ There is

\footnotetext{
${ }^{4}$ Ibid., 614 and literature cited there.

5 FH Lawson, International Encyclopaedia of Comparative Law, vol VI, ch 2, para 42, cited by Gretton (n3) 614.

${ }^{6}$ See Art 2011 of the French Civil Code: "la fiducie est l'opération par laquelle un ou plusieurs constituants transfèrent des biens (...) à un ou plusieurs fiduciaires qui, les tenant séparés de leur patrimoine proper..."; see also art 2025 of the French Civil Code.

7 Art 915 of the Principality of Liechtenstein Trusts Law: "the trust estate is to be treated as a separate patrimony and the creditors of the trustee have no claim on it", cited in Gretton (n3), fn 73.

${ }^{8}$ Gretton (n3) 614.

${ }^{9} \mathrm{M}$ de Waal, 'In Search of a Model for the Introduction of the Trust into a Civilian Context' (2001) 12 Stellenbosch L Rev 63, 67.

10 See in particular Gretton (n3), at fn 67.

11 The other two being the fiduciary position of a trustee; the office of a trustee. de Waal (n9), 6667; see also T Honoré, 'Obstacles to the Reception of Trust Law? The Examples of South Africa and Scotland' in A Rabello (ed) Aequitas and Equity. Equity in Civil Law and Mixed Jurisdictions (1997) 793.
} 
therefore a temptation to equate the separate patrimony with the trust fund and tracing with real subrogation. The inclination to do so is strong because first, the immunity of the fund/patrimony from claims of the trustee's creditors is prima facie ensured by the segregation of the fund/patrimony from the rest of the assets of the trustee and, second, the beneficiary's ability to assert a claim to assets acquired with the exchange value of the original trust asset seems to be explicable as much by tracing as it is by real subrogation. If one of the crucial features of the common law trusts is that beneficiaries can assert a proprietary claim to traceable proceeds against third parties, the question then is whether real subrogation and separate patrimony could provide for as much or explain a parallel claim in civil law.

In exploring the parallels that can be drawn between the separate patrimony and real subrogation in civil law systems and the trust fund, tracing and claims contingent on tracing in common law systems, this paper deals with some of the misconceptions that exist in this area. First, the paper challenges the views that reify patrimonies and trust funds. It is argued that a patrimony is not a res. An attempt is made to explain how separate patrimonies work in civil law and how it is possible to overcome the objection to the trust fund as a separate patrimony that the trustee is liable for trust debts in his own capacity, not in the capacity as a trustee. ${ }^{12}$ The paper goes on to explain the mechanisms of real subrogation and challenges the common assumption that real subrogation is an equivalent of tracing ${ }^{13}$. It is further shown that the exercise of the trustee's powers of disposition achieves an outcome similar to the type of real subrogation that operates within separate patrimonies. This is true of authorised dispositions of the assets. When the dispositions by the trustee or a manager of a separate patrimony are unauthorised, both real subrogation and the trust concept struggle to explain the rights of the fund beneficiaries and it may be necessary to turn to other mechanisms of claiming.

\footnotetext{
12 L Smith, 'Trust and Patrimony' (2008) 38 Revue Générale de Droit 9; reprinted in (2009) 8 Estates Trusts and Pensions Journal 332.

13 See eg G Gretton, 'Constructive Trusts I' (1997) 1 Edin L Rev 281, 291 and 297-298; V Sagaert, 'Cour De Cassation Française, 26 Avril 2000 - Priority Conflict between the Seller under Title Retention and the Assignee of the Resale Claim' (2002) 10 European Rev of Private Law 823, 823.
} 
The approach developed here is based primarily, although not exclusively, on the English trust as an example of a common law trust, and the Polish doctrine of real subrogation. The choice of Polish law has been dictated by insights it offers as a civil law jurisdiction derived from mixed French and German legal traditions. References to Roman law are crucial because a misunderstanding of the original sources inhibits the comprehension of the present day concepts.

\section{The concept of a separate patrimony}

\section{A. The meaning of the segregation}

In civil law every person has a patrimony even if it is an empty one ${ }^{14}$. Sensu largo it comprises everything one owns, is owed and owes ${ }^{15}$; sensu stricto patrimonium covers only assets, not liabilities. ${ }^{16}$ The purpose of grouping of all one's assets around a person is so that the creditors of a person can enforce their claims against all these assets. ${ }^{17}$ Thus, any liabilities incurred by $\mathrm{A}$ are enforceable against A's patrimony, which means that A's assets are available for seizure and sale to satisfy claims of the judgment creditors (universal patrimonial liability). ${ }^{18}$ The French ${ }^{19}$ and Quebec Civil Codes $^{20}$ refer to this as

14 Smith (n12), 13.

15 Z Radwański, Prawo Cywilne - Część Ogólna (CH Beck, Warszawa 2007) 139; Cf Smith (n12) 13; see also in Scots law SL Commission, Discussion Paper on the Nature and the Constitution of Trusts (The Stationery Office, Edinburgh 2006) 10 at 2.16.

16 Radwański (n15) 139; see also A Dyoniak, 'Pojęcie Majątku W Prawie Cywilnym' (1985) 11-12 PiP 119139 (favouring the narrower interepretation of the patrimony in Polish civil law).

17 This theory of general patrimony was developed by French scholars Aubry and Rau, see C Aubry and C Rau, Cours De Droit Civil Français (7th edn Paris 1919).

18 H Hansmann, R Kraakman and R Squire, 'Law and Rise of the Firm' (2006) 119 Harv L Rev 1335, 1337; see N Kasirer, 'Translating Part of France's Legal Heritage' (2008) 38 Revue Générale de Droit 453463; see art 2284 of the French Civil Code (former art 2092): "Quiconque s'est obligé personnellement, est tenu de remplir son engagement sur tous ses biens mobiliers et immobiliers, présents et à venir"; the same principle exists in Polish law but it has not been codified, W Czachórski, A Brzozowski, M Safjan and W Skowrońska-Bocian, Zobowiqzania (LexisNexis, Warszawa 2003) 61; see also art 2645 of the Civil Code of Québec: "Any person under a personal obligation charges, for its performance, all his property, movable and immovable, present and future, except property which is exempt from seizure or property which is the object of a division of patrimony permitted by law."

19 Art 2285 of the French Civil Code: "Les biens du débiteur sont le gage commun de ses créanciers ; et le prix s'en distribue entre eux par contribution, à moins qu'il n'y ait entre les créanciers des causes légitimes de préférence." The concept of "gage commun" is not present in Polish law.

20 Art 2644 of the Civil Code of Québec: "The property of a debtor is charged with the performance of his obligations and is the common pledge of his creditors." 
gage commun, a right of general pledge on all the assets of A where that the creditors were the pledgees.

Polish law, following German scholarship, has also recognised the concept of a separate patrimony (or a separate fund ${ }^{21}$ ), defined as a particular set of assets ${ }^{22}$ which is segregated from another set of assets (usually the patrimony) in the following way. Even though both sets of assets belong to the same person, the separation of one set from another enables exchanges between the two sets of assets as if they belonged to two different persons. ${ }^{23}$ Although there is no definition of a separate fund in Polish legislation, a number of provisions refer to it, for instance the Civil Code provisions on the separate fund of spouses ${ }^{24}$, the partnership fund ${ }^{25}$ or the inheritance fund before it is split between heirs and becomes a part of their patrimonies ${ }^{26}$.

\section{(a) Protection of separate patrimonies from otherwise enforceable claims}

Matrimonial regimes are a good example to illustrate the workings of separate patrimonies. In Poland, from the moment a marriage is concluded, a community of property is formed. ${ }^{27}$ Assets acquired by either or both spouses during the marriage, in particular collected wages or pension ${ }^{28}$, are owned jointly and become a part of the so-called common patrimony. Assets, which fall outside of common patrimony, form separate property of each of the spouses ( $\mathrm{H}$ and $\mathrm{W}){ }^{29}$ They include assets acquired before marriage or assets inherited during the marriage. This means that H's own assets are immune from W's creditors and,

\footnotetext{
21 Polish majątek odrębny, German Sondervermögen, Sondergut. This paper does not draw linguistic differences between a separate patrimony and a separate fund.

22 Polish definition uses the phrase "valuable right" meaning a right of value, transferrable (assignable) right. This includes rights to assets, such as an ownership of an asset. A collection of bikes is thus perceived as a collection of rights to bikes. It seems that in English the term "assets", which covers intangibles including rights, conveys the meaning better than the civilian "right".

${ }^{23}$ E Kitłowski, Surogacja Rzeczowa w Prawie Cywilnym (Warszawa 1969) 14. Cf A v Tuhr, Der Allgemeine Teil des Deutschen Bürgerlichen Rechts (Monachium 1957) 340: "Die Selbstständigkeit des Songerguts gegenüber dem allgemeinen Vermögen des Subjekts zeigt sich besonders deutlich daran, dass zwischen beiden massen Rechtsbeziehungen möglich sind, wie sie sonst nur zwischen verschiedenen Personen vorkommen".

24 Arts 31-51 of the Polish Code of Family and Tutelage of 25 February 1964, Official Journal 1964/9/59, subsequently changed.

${ }^{25}$ Arts 863-875 of the Polish Civil Code.

${ }^{26}$ Arts 1030 of the Polish Civil Code.

${ }^{27}$ Art $31 \S 1$ of the Polish Code of Family and Tutelage.

${ }^{28}$ Art $31 \S 2$ of the Polish Code of Family and Tutelage.

${ }^{29}$ Art $31 \S 1$ of the Polish Code of Family and Tutelage.
} 
analogously, W's own assets cannot be claimed by H's creditors. If the other spouse (say H) agreed to his W's debt, then W's creditors can resort to the property owned by $\mathrm{H}$ and $\mathrm{W}$ jointly to pay the debt (the common patrimony) ${ }^{30}$ but they still cannot claim against H's separate patrimony. The Polish law on matrimonial property regimes changed significantly on 17 June $2004^{31}$. Prior to the reform, a creditor of only one spouse (say W) could resort to W's separate patrimony and to the common patrimony even if $\mathrm{H}$ did not expressly consent. After the reform, creditors of W's debts can only enforce their claims against W's separate patrimony. This had significant consequences for banks. Typically, before the reform if $\mathrm{H}$ borrowed money from a bank, the bank could enforce the claim against H's assets as well as H's and W's common assets. After the reform, the bank must seek consent from $\mathrm{W}$ in order to claim against the spouses' common assets. If the bank fails to do so, it can only claim against H's own assets. The reform is significant to our understanding of separate patrimonies also for other reasons, which are discussed below, but for the moment the key observation is even before the reform the separate patrimony of $\mathrm{H}$ would have been immune from claims of W's creditors. This supports the view that separate patrimonies protect assets within them from execution of claims of creditors of another person. In other words, when we talk about a separate patrimony of a person entitled to it $(\mathrm{H})$, what we usually mean is that the separate patrimony will be immune from another person's creditors (e.g. claims of W's creditors), who could, were it not for the separate patrimony, seize the assets within the separate patrimony. ${ }^{32}$ However, there is not necessarily a corresponding liability of the separate patrimony (and only the separate patrimony) to pay debts made in connection to it.

\footnotetext{
${ }^{30}$ Art $41 \S 1$ of the Polish Code of Family and Tutelage

${ }^{31}$ Law reform of 17 June 2004, OJ 162/1691, in force from 20 January 2005.

32 Following this definition, W's own patrimony can only be labeled as a "separate patrimony" if we agree that W would otherwise be (at least perceived as) liable for H's debts, i.e. H's creditors could direct their claims against W and W's (all) assets. If there is no basis on which to say that W and H share debts, their debts remain separate and a situation when one spouse's creditors would claim against another spouse's assets never arises. In such a cases there is no point in talking about their respective "separate patrimonies" because there is nothing these would be 'separate' from.
} 


\section{(b) Liability for debts incurred with respect to separate patrimonies}

In Polish law the liabilities incurred with respect to assets belonging to a separate patrimony tend to be enforceable from a separate patrimony. For instance, if a spouse is a liable to pay 1000 PLN for redecorating her own house, which does not belong to the common patrimony, and she does not pay, the decorating company will be able to claim against the house or other assets in the spouse's separate patrimony, but not against the assets within the common patrimony. ${ }^{33}$ This does not have to be the case, however. It is not inherent in the definition of a separate patrimony that debts incurred with respect to the separate patrimony must be paid, voluntarily or enforced, from the separate patrimony. As mentioned above, under the law pre-17 June 2004 a wife's personal creditor could look to both wife's own assets and the assets she owned jointly with her husband. The creditor was limited to seize and sell assets belonging only to the wife's patrimony. Yet, this did not defeat the existence of the wife's separate patrimony. This observation should be kept in mind when we look at Professor Lionel Smith's objection to Lepaulle's characterization of the trust fund as a separate patrimony.

Lepaulle understood the trust as a patrimony affected to a destination or purpose, which belittled the role of trustees and beneficiaries. ${ }^{34}$ Smith rightly questioned this approach on the basis that the common law trust cannot exist without the beneficiaries or the trustee. ${ }^{35}$ Smith also made a point that the fact that the creditors of the trust can claim against the trustee as a person and not the trustee in the capacity of the trustee, indicates that the trust cannot be equated with a separate patrimony. Yet, the evidence from Polish law on debts arising from matrimonial property regime law helps to explain that the two are not mutually exclusive: an owner of a separate patrimony does not necessarily need to be sued in such capacity for there to be a separate patrimony. We have seen that in Poland debts relating to a debtor's separate patrimony can be

\footnotetext{
${ }^{33}$ Art $41 \S 2$ of the Polish Code of Family and Tutelage. If it was the husband dealing with the decorator, however, the unpaid decorators would be able to enforce the claim against the common patrimony as the husband will be deemed to have consented.

${ }^{34} \mathrm{P}$ Lepaulle, Traité Théorique et Pratique des Trusts en Droit Interne, en Droit Fiscal et en Droit International (Rousseau et Cie, Paris 1931) fn 4 at p 31, cited in Smith (n12) 11.

${ }^{35}$ Smith (n12) 14.
} 
enforced from both the separate patrimony of a spouse-the debtor and the common patrimony. ${ }^{36}$ Thus a separate patrimony remains a meaningful concept even if that separate patrimony is not exclusively liable for debts relating to it.

The concept of a separate patrimony remains relevant for the purposes of excluding claims of the other spouse's creditors. Therefore, it is argued, the existence of a separate patrimony could be seen as functionally equivalent to the trust fund insofar as the protection from a certain groups of creditors (trustee's creditors) is concerned.

\section{B. Exchangeability of the assets as an element of the separate patrimony}

Assuming that functional parallels can be drawn between a trust fund and a separate patrimony, as the previous section attempted to show, we must now turn to their rationale, which is to enable a person to enjoy continuing rights in a fluctuating group of assets. ${ }^{37}$ The question is whether the exchangeability of contents of within a patrimony is essential for the patrimony to be separate. The content of patrimonies is rarely static. Perhaps a collection of old paintings held only for the enjoyment of the paintings themselves could be an example of such a rare "static" patrimony. In most patrimonies assets are sold, exchanged or otherwise disposed of, thus producing proceeds, which in turn gives rise to a question whether the proceeds should automatically return to the patrimony for it to be separate.

In Poland, art 33(10) of the Polish Code of Family and Tutelage provides that assets acquired with the means from the personal patrimony of one of the spouses belong to that patrimony. ${ }^{38}$ This provision exists, however, only since the Family and Tutelage Code reform of 17 June $2004 .{ }^{39}$ Prior to the change the wording was to the opposite effect. Assets acquired after marriage with spouses' own means did not enter the personal patrimonies of the spouses but the

\footnotetext{
${ }^{36}$ After 17 June 2004 only if the other spouse consented, see above.

37 R Nolan, 'Property in a Fund' (2004) 120 LQR 108109; E McKendrick (ed), Goode on Commercial Law (4th edn Penguin Books, 2010) 65-66; FH Lawson and B Rudden, The Law of Property (3rd edn OUP, Oxford 2002) 44-46.

${ }^{38}$ Art 33(10) of the Polish Code of Family and Tutelage. See eg resolution of the Polish Supreme Court of 11 September 2003, III CZP 52/03.

${ }^{39}$ See above, section $2 \mathrm{~A}(\mathrm{i})$.
} 
common patrimony, the result being a progressive shrinkage of the "size" (value) of the personal patrimonies. Even though the reform reversed the effect of a transfer of assets from the personal patrimonies, it has not been questioned that both before and after the reform the spouses had personal (separate) patrimonies. This suggests that exchangeability of assets within a patrimony is not a crucial element of a separate patrimony. Patrimonies may be separate irrespectively of whether or not the substitutes are caught automatically by a patrimony. An argument to the contrary ${ }^{40}$ has been drawn on the basis of German fiduziarische Treuhand.

If the Treuhänder becomes insolvent, the assets held by him in Treuhand fall into his bankrupt estate unless they have been transferred to him directly by the settlor $^{41}$, pursuant to the court-affirmed Unmittelbarkeitsprinzip ${ }^{42}$. The principle developed gradually. According to the early twentieth century Reichsgericht jurisprudence, the creditors of the "trustee" could not seize "trust" property if it was "properly ear-marked" and therefore distinguishable ${ }^{43}$ because it would have been considered as a windfall for these creditors. ${ }^{44}$ Courts subsequently 45 limited this to property transferred directly from the settlor to the trustee, which meant that the traceable proceeds of the original property fell within the "trustee's" own estate (Surrogationsverbot). Thus, even if trust property was regarded as belonging to a separate patrimony it was not regarded as including accessions, replacements or proceeds of sale of the original assets unless these

\footnotetext{
40 Gretton (n3) fn 67. Professor George Gretton remarked that it is irreconcilable with a notion of a special patrimony because "if there is a special patrimony then there must be real subrogation.

41 Since most "trusts" in Germany are said to be inter vivos for settlor's own benefit, some German authors refer to settlors as having the beneficial ownership (as distinct form legal ownership) but it seems that even if that is the case it is conceptually clearer to use the different terms - beneficiary and settlor - as non-synonymous.

42 Decisions of Reichsgericht RGZ 84, 214, at 217; RGZ 91, 12, at 16; RGZ 133, 84, at 87; decision of Bundesgerichtshof BGHZ 1959, Entscheidungen des Bundesgerichtshofes in Zivilsachen $p$ 1223, cited in C Rounds and A Dehio, 'Publicly-Traded Open End Mutual Funds in Common Law and Civil Law Jurisdictions: A Comparison of Legal Structures' (2007) 3 NYUJLBU 473 fn 85. The term Unmittelbarkeitsprizip (principle of immediacy of transfer) was coined by Friedmann, 36 DJT 1930, Vol I, 805 at 862, as cited in S Grundmann, 'Trust and Treuhand at the End of the 20th Century. Key Problems and Shift of Interests' (1999) 47 Am J Comp L 401, 408 fn 34

${ }^{43}$ Grundmann (n42) 407, citing RGZ 45, 80 at 83-87 and RGZ 79, 121 at 122 et seq, described as the principle of certainty - Bestimmtsheitsgrundsatz.

44 RGZ 45, 80 at 84; RGZ 79, 121 at 123, cited in Ibid., fn 33.

45 RGZ 84, 214 at 217; RGZ 91, 12 at 16; RGZ 127, 341 at 344 et seq; RGZ 133, 84 at 87; RGZ 160, 52 at 59; BGH NJW 1959, 1223 at 1224; BGH WM 1964, 179 at 179; OLG Köln ZIP 1984, 473 at 475, cited in Grundmann (n42) 408 at fn 34 and see literature there.
} 
have been conveyed to the settlor and resettled. ${ }^{46}$ This excludes transfers from third parties, particularly when bank accounts are involved held in "trust" by a notary or a lawyer. ${ }^{47}$ There are views advocating the return to the original principle: that the beneficial interest be protected each time the property can be distinguished from other assets (Bestimmtsheitsgrundsatz). ${ }^{48}$ The Unmittelbarkeitsprinzip is, however, misapplied in the German mutual fund context. If a mutual fund is construed under German law on the basis of Treuhand ${ }^{49}$, which is particularly useful in the case of collective investments in real property 50 , the investors transfer monies to the KAG (Kapitalanlegegeselschaft) and KAG administers the underlying assets of a mutual fund (Sondervermögen). ${ }^{51} \mathrm{KAG}$ is then the title holder to the underlying assets. $^{52}$ The separate investment fund is segregated from KAG's own assets. ${ }^{53}$ According to Unmittelbarkeitsprinzip only the monies initially paid in the fund by investors would be protected from creditors of the Treuhänder. The effect would be incompatible with the concept of an open-ended mutual fund. Hence, the principle was neutralised legislatively in $§ 30$ II of the German Investment Law. ${ }^{54}$ All investments within the Sondervermögen accrue to the Sondervermögen and are protected from Treuhänder's creditors.

\footnotetext{
${ }^{46}$ A Honoré, Book Review: The British Commonwealth in International Law by JES Fawcett (1964) 13 ICLQ 713, 736.

47 BGH NJW 1954, 190 at 191; BGH 7.4.1959, NJW 1959, 1223 at 1225; BGH NJW 1971, 559 at 560, cited in Grundmann (n42) 408 fn 35.

${ }^{48}$ Grundmann (n42) 408-409 and see also other proponents of this view cited there cited there.

49 Under German law, a mutual fund can be construed as the Treuhandlösung - an imperfect common law trust, or the Miteigentumslösung - an imperfect common law tenancy in common, see Rounds and Dehio (n42) 496.

50 Every ownership transfer of real property must be registered in the land register (Grundbuch) in order to take effect (Offenkundigkeitsprinzip). Without a single entity to hold the title, such as the KAG, each investor would have to be registered in the Grundbuch to effect their pro rata share of the collective ownership (Bruchteilsgemeinschaft), rendering the investment process, which it was designed to achieve, impracticable. See Rounds and Dehio (n42) 498.

51 §2 II German Investmentgesetz. KAG has a special banking license issued by the German Federal Banking Agency - Rounds and Dehio (n42) 496.

$52 \S 30$ I Investmentgesetz,

53 §30 I Abs. 2 Investementgesetz: "Das Sondervermögen ist von dem eigenen Vermögen der Kapitalanlagegesellschaft getrennt zu halten".

$54 \quad \$ 30 \quad$ II Investmentgesetz: "Zum Sondervermögen gehört auch alles, was die Kapitalanlagegesellschaft auf Grund eines zum Sondervermögen gehörenden Rechts oder durch ein Rechtsgeschäft erwirbt, das sich auf das Sondervermögen bezieht, oder was derjenige, dem das Sondervermögen zusteht, als Ersatz für ein zum Sondervermögen gehörendes Recht erwirbt."
} 
It has therefore been argued that the German mutual fund investor is essentially endowed with a "quasi-property interest in Sondervermögen, the title to which is in the KAG".55 The parallels with a common law beneficiary's equitable title should not be drawn too hastily, however. Unlike the common law beneficiary in the breach of trust by the trustee, the "beneficiary" of a German Treuhand has merely contractual remedies in case of a harm done to the Sondervermögen by the Treuhänder.

It seems that exchangeability of assets is not as such an indispensable element of a separate patrimony. A patrimony may still be separate even if proceeds of a disposition of patrimonial assets fall outside of the patrimony. However, there is a good argument that in order to achieve a particular outcome within a separate patrimony, traceable proceeds must inhere within the patrimony. Simply because a patrimony is separate does not mean that its contents may not change: assets may be both taken out or added in. Further, the Unmittelbarkeitsprinzip, coupled with the Surrogationsverbot, does not seem to be incompatible with a separate patrimony but they most probably are so if the separate patrimony is managed for the benefit of someone.

\section{Types of separate patrimonies}

It is suggested that the extent to which separate patrimonies are "separate" varies in civil law. At one end of the spectrum is the type of patrimony where assets are segregated from a person's (A's) other assets in such a way that A's personal creditors have no access to them and any liabilities arising from that pool of assets are satisfied by seizing and selling these assets. Creditors of such a separate patrimony cannot seek enforcement of their claims from A's own assets unless they are part of the separate patrimony. This can be described as "asset independence", or affirmative asset partitioning, as it is known in the US. ${ }^{56}$ Assets are subtracted from the common pledge of A's personal creditors as each pool of assets is bonded to a different purpose. ${ }^{57}$ Such a fund could be called a separate patrimony par excellance or a stronger version of a separate patrimony.

\footnotetext{
55 Rounds and Dehio (n42) 500.

${ }^{56}$ GR Elgueta, 'Divergences and Convergences of Common Law and Civil Law Traditions on Asset Partitioning: A Functional Analysis' (2010) 12 U Pa J Bus L 517

57 Ibid., 525.
} 
An example of such a patrimony is the Italian "committed funds" introduced in the Italian Civil Code in 2003. ${ }^{58}$ An Italian corporation may partition up to 10 percent of its asset in order to commit them to a specific business purpose. These assets are pledged only to those creditors whose claim is related to the specific business purpose ("specialized creditors"). The general creditors of the corporation have no recourse against this separate fund (affirmative asset partitioning). Equally, the specialized creditors cannot claim against the corporation's assets, which are not part of the committed fund (defensive asset partitioning). ${ }^{59}$ The functional equivalent of this type of separate patrimony is a corporate subsidiary. ${ }^{60}$

A weaker version of the separate patrimony insulates the assets from A's creditors but the liabilities incurred with respect to the separate patrimony may be satisfied by enforcement not only against the assets within the separate patrimony but also against A's own assets. This pattern seems to be followed by the French fiducie. ${ }^{61}$ An independent patrimony (patrimoine fiduciaire) is created, which is separate from the patrimonies of both the settlor (constituant) and the fiduciary (fiduciaire) and thus immune from claims of either the settlor's or fiduciary's creditors. No assets can be seized from the fiduciary patrimony to satisfy claims others than those arising from the management or preservation of the fiduciary patrimony. ${ }^{62}$ However, if the assets within the fiduciary patrimony are insufficient to pay the creditors, the latter can seize assets within the patrimony of the settlor ${ }^{63}$ unless the contract creating the fiducie provides otherwise.

\section{Real subrogation as a mechanism for asset exchangeability}

\footnotetext{
${ }^{58}$ Arts 2447 bis - 2447 decies of the Italian Civil Code.

59 Elgueta (n56) 534.

${ }^{60}$ A subsidiary can be incorporated for other reasons too.

${ }^{61}$ Art 2011 et seq of the French Civil Code.

${ }^{62}$ Art 2025 al. 1 of the French Civil Code: "Sans préjudice des droits des créanciers du constituant titulaires d'un droit de suite attaché à une sûreté publiée antérieurement au contrat de fiducie et hors les cas de fraude aux droits des créanciers du constituant, le patrimoine fiduciaire ne peut être saisi que par les titulaires de créances nées de la conservation ou de la gestion de ce patrimoine (emphasis - MR)."

63 There is a gage commun over the patrimony of the settlor, art 2025 al 2 of the French Civil Code.
} 
Even though asset exchangeability falls short of a condition sine qua non of every separate patrimony, it may play a crucial role if the effect that we are after is a fluctuating fund of assets. Exchangeability (or substitution) of assets in civil law systems is usually linked with real subrogation.

Real subrogation developed in Roman $\operatorname{law}^{64}$ to operate within collections of assets. On the basis of Roman law, the following Pandectist maxims ${ }^{65}$ have been developed to illustrate the process of asset substitution within funds: in universalibus res succedit in loco pretii et pretium in loco rei (in the context of collections of assets a thing takes the place of a price and the price takes the place of the thing); in singularibus res non succedit loco pretii nec res loco rei (when particular assets are concerned the price does not substitute the assets nor the asset substitutes the price). ${ }^{66}$ Thus the second maxim excluded the application of subrogation where entitlements to particular assets were concerned.67 The third maxim pertains to the effects of real subrogation: subrogatum capit naturam subrogatii: the substitute takes the nature of the substituted asset. The meaning of "capit naturam" is far from clear.

The application of real subrogation has been extended to explain not only rights to substitutes within separate patrimonies or general patrimonies (such as rights to common pledge ${ }^{68}$ ), but also to explain how particular rights could apply to substitutes when a collection of assets was not involved, thus contradicting the

\footnotetext{
${ }^{64}$ A prototype mechanism for asserting rights in substituted assets developed in Greek law in connection with a contract of sale. L. Winkel, 'Some remarks on substitution of property and unjust enrichment in European legal history' in E Schrage (ed), Unjust Enrichment and the Law of Contract (Kluwer Law International, The Hague, London, New York 2001) 441, at 442 citing F Pringsheim, Der Kauf mit fremdem Geld (Leipzig 1916); F Pringsheim, The Greek Law of Sale (Weimar 1950).

65 V Ranouil, La Subrogation Réelle En Droit Civil Français (Bibliothèque De Droit Privé, Paris 1985) 58-59 (explaining all three maxims); Kitłowski (n23) 8.

66 The origins seem to be in D 5,3,22 Paulus libro vicensimo as edictum; see A Santos, Subrogación Real Y Patrimonios Especiales En El Derecho Romano Clásico (Universidad de Valladolid: Secretariado de Publicaciones E Intercambio Cientifico, 1997) 90; J Flach, De La Subrogation Réelle (Paris 1870) 21.

67 Ranouil (n65) 58. Exceptions are when legislative provisions allow asset substitution without any separate fund,

68 Real subrogation was key to Aubry and Rau's concept of general patrimony, Aubry and Rau (n17) $340 \mathrm{ff}$.
} 
second Pandectist maxim. As a result, subrogation within separate funds ${ }^{69}$ has been traditionally distinguished ${ }^{70}$ from subrogation outside of such funds. ${ }^{71}$

\section{A. Two types of real subrogation}

\section{(a) Real subrogation within separate funds (in universalibus)}

Real subrogation of assets within collections of assets is the archetype or real subrogation, reflected in the first Pandectist maxim. It is controversial whether this type of real subrogation may operate within any separate fund or solely when so provided by law. There is an argument that whenever means from (any) separate fund are used to acquire an asset, the asset should fall into the separate fund, notwithstanding the lack of a specific legislative provision. ${ }^{72}$ This seems right but it is important to remember that the presence of a legislative provision that takes new assets outside of the scope of a separate patrimony when assets inhering in it have been exchanged for the new assets, does not preclude that a separate patrimony exists. ${ }^{73}$

Separate funds serve to fence off the assets and make them unavailable to a certain group of potential creditors. Real subrogation preserves that quality in assets newly-acquired with the means from separate funds. The result is that if the old asset was immune from some creditors' claims, the new asset will also be protected against such creditors' claims. Real subrogation in separate funds does not operate to subject substitutes to the same right as the original asset but rather it transfers a particular attribute, which the previous right had. Therefore,

\footnotetext{
${ }^{69}$ Polish surogacja w składzie majątku odrębnego, German Universalsurrogation.

70 Kitłowski (n23) 13; S. Grzybowski, in S. Grzybowski (ed.) System prawa cywilnego. Część ogólna, vol 1 (Wrocław, Warszawa, Kraków, Gdańsk, Łódź, Ossolineum, 1985), p.472.

${ }^{71}$ Polish surogacja poza majątkiem odrębnym, German Singularsurrogation.

72 A Ohanowicz, 'Case Comment to Supreme Court Ruling of 18 October 1961, 4 Cr 957/60' (1962) 8-9 PiP 465. A view to the contrary was presented by S Szer, 'Case Comment to Supreme Court Ruling of 24 November 1963' (1963) OSPIKA 1963/240/538 538. To give a brief example, the Civil Code does not provide expressly for asset substitution within a fund of a partnership running a business. Yet, it seems that if real subrogation was not allowed, notwithstanding the lack of a specific provision, it would impede the partnership's performance.

${ }^{73}$ See Polish matrimonial regime before the reform of 17 June 2004, discussed above, see section 2B.
} 
where separate funds are involved, it is wrong to say that a new asset becomes subject to the same right as the old asset. ${ }^{74}$

The new asset must be sufficiently linked with the old one to become an element of the separate fund. A transactional link is necessary but not sufficient. It is not clear whether a causal link, or else, is needed. In German law this additional requirement is epitomized in the phrase "acquired with the means from"75 the separate fund, supplemented by an intention that the substituting act relates to the separate fund..$^{76}$ What is clear, however, is that it is insufficient for one event to be only a pretext for another to happen (i.e. a mere causal link is insufficient), for instance where a gift from A to B of an asset from her separate fund provokes a gift in reciprocation from $B$ to A. Likewise, if an asset is excluded from the fund and by reason of this exclusion a new asset arises for the benefit of a third party, not the fund owner, the new asset will not be considered to be a substitute of the old one. To illustrate, if a thief stole an antique clock from a separate fund (such as the inheritance fund), and subsequently sold it, the only right that will arise within the separate fund will be a tort claim ${ }^{77}$ against the thief, not the thief's right to claim a purchase price, which the thief might have obtained if he had entered into a sale contract and the other party has not yet performed his part of the bargain..$^{78}$ The situation may change if the separate fund is in the hands of a third party possessor, for instance when an administrator temporarily manages an inheritance fund for the heirs. In such a case, if the possessor of the fund acts outside of his powers, anything acquired with means from the inheritance fund

\footnotetext{
${ }^{74}$ Similar conclusion on different arguments Kitłowski 23; what I refer to in this paper as the transfer of particular attributes has lead some authors to argue that real subrogation in civil law is in fact an method of primary, rather than derivative, acquisition (mode originaire d'acquisition) E Savaux, 'Subrogation Reélle' (mars 1998) Rep civ Dalloz (I am very grateful to Rafael Ibarra Garza for providing me with this source).

75 See §2019 BGB: “Als aus der Erbschaft erlangt gilt auch, was der Erbschaftsbesitzer durch Rechtsgeschäft mit Mitteln der Erbschaft erwirb.” (emphasis - MR).

${ }^{76}$ German law seems to require that the substituting act relate to the separate fund, e.g. that the person doing the substituting act does so with the intention that the substitute enters the separate fund. See R Beyer, Surrogation bei Vermögen (Mahrburg 1905) 222, cited in Kitlowski (n23) 21.

77 The use of "tort claim" can be confusing. By "tort claim" in this context it is meant that the person whose asset was stolen will be able to demand that the wrongdoer make up for the loss. This in turn can be achieved by financial compensation or restitution (restitutio ad integrum), Czachórski, Brzozowski, Safjan and Skowrońska-Bocian (n18) 107-108.

${ }^{78}$ Kitlowski (n23) 22.
} 
will be deemed to have been obtained as a part of the inheritance. ${ }^{79}$ This is because both the old asset and the new asset will be considered to have been managed for the benefit of the third party (the heirs).

\section{(b) Real subrogation outside of separate funds (in singularibus)}

For a real subrogation to operate outside of separate funds, legislative provisions are crucial to provide the framework within which the subrogation can operate. ${ }^{80}$ Examples are the Polish hypothec and the right to substitutes under unjust enrichment. If a mortgaged building is destroyed, the secured creditor will be able to shift its security interest to the insurance benefit paid upon the event. ${ }^{81}$ Likewise, in the case of unjust enrichment, pursuant to article 406 of the Polish Civil Code, the enriched must return anything which he received as a result of the disposition, loss or damage to the enrichment ${ }^{82}$, subject to the change of position defence. ${ }^{83}$ In other words, the person entitled to use or have the old asset for a certain purpose, such as for instance the purpose of satisfying the creditor's debt in case the debtor does not pay, will be able to assert his right in the new asset in the same way, i.e. use the new asset for the same purpose.

It seems also that there must be a relationship between the old asset and the new one. An asset which came about without any connection with the exclusion of the old asset cannot be regarded as a substitute. ${ }^{84}$ Whilst for real subrogation to apply within separate patrimonies more than a transactional link is necessary, ${ }^{85}$ for real subrogation to operate outside of separate patrimonies a transactional link suffices. It certainly need not be causal.86 One of the implications of this is that multiple substitutions are less problematic when merely a transactional link is needed. Hence, real subrogation is seen as easier to apply when in singularibus than when in pluralibus due to a requirement of more than merely a transactional link need in the latter case.

\footnotetext{
${ }^{79} \S 2019$ BGB. There is no equivalent provision in Polish law. Kitłowski (n23) 22.

80 Without a clear provision one asset cannot simply substitute another.

81 Article 93 of the Law on Land Registers and Hypothecs of 6 July 1982, Official Journal 2001/124/1361, amended subsequently.

82 Article 406 of the Polish Civil Code.

83 Article 409 of the Polish Civil Code.

${ }^{84}$ Kitłowski 29 citing R Beyer as authority on this (R Beyer, Surrogation bei Vermögen (Mahrburg 1905) 8).

85 Or at least some additional requirement relating to the substituting act was required.

${ }^{86}$ Kitłowski (n23) 29
} 
We can illustrate the difference between the two types of real subrogation by returning to the thief who stole an antique clock from an inheritance fund of $\mathrm{H}$. When the thief sells the clock to a third party, a tort claim arises in the separate fund of $\mathrm{H}$, which means that the tort claim will be protected from seizure by H's own creditors in the same way that the clock was. ${ }^{87} \mathrm{H}$ will not be able to claim in this way any right to the price the thief might obtain by selling the clock a third party. The right to the purchase price will not enter the inheritance fund. However, when $\mathrm{H}$ makes an unjust enrichment claim against the thief, on the basis of Article 406 of the Polish Civil Code, $\mathrm{H}$ can claim the purchase price as a result of the disposition by the thief to the third party but that claim will not be protected against H's creditors. This is because whilst the thief's wrongdoing was a cause for a tort claim to arise within the separate patrimony, the right to the purchase price did not arise by the same act, which caused the original asset to leave the patrimony, i.e. the thief's wrongdoing. The right to be paid the purchase price arose in the hands of the thief as a result of the thief's sale of the asset to a purchaser. Alternatively, it could be said that the right to the purchase price does not "enter" the separate patrimony because it arose not in relation to the separate patrimony of $\mathrm{H}$.

\section{B. Nature of the substitution: old or new right to the new asset?}

One of the most perplexing problems of real subrogation is the nature of the substitution. It seems that according to the Pandectist approach the right in the new substitute is the continuing property right transferred from the old asset. There are views, however, that the result of the substitution of assets generates a new right, the object of which is the new asset. On that view, the essence of subrogation is to preserve the wealth for the benefit of the entitled person. For instance, if an asset identified in specie was destroyed in circumstances, which the debtor is not liable for, the debtor will be obliged to pass over to the creditor the compensation claim he may have. ${ }^{88}$ Thus the creditor will acquire a new right in the substitute. The new asset will serve the creditor in the same way as the old

\footnotetext{
${ }^{87} \mathrm{H}$ 's creditors cannot seize the tort claim in the sense that they cannot make the claim instead of $\mathrm{H}$ but they may have the right to seize for instance damages that will arise on the basis of the claim which $\mathrm{H}$ had made.

${ }^{88}$ Article 474 Polish Civil Code.
} 
asset did: by providing a realizable value. ${ }^{89}$ Consequently, real subrogation outside of separate funds may be better characterized as a process that allows the entitled person (e.g. the disenriched or the chargee) to use the proceeds for the same purpose, which the original asset was to fulfill.

It follows that real subrogation is different from the evidentiary process of identifying misappropriated value, which is tracing ${ }^{90}$. Whether operating in universalibus or in signularibus, real subrogation ensures that the person availing herself of real subrogation, is left with a claim/right to the new asset. It may not necessarily be the same right, which one had to the original asset; it just means that if $A$ was entitled to an asset ( $\left.\mathrm{a}_{0}\right)$, real subrogation will enable $\mathrm{A}$ to claim $\mathrm{a}_{\mathrm{n}}$ as long as it is at least transactionally linked to $\mathrm{a}_{0} .{ }^{91}$ It must be remembered that real subrogation operates in a limited number of circumstances. Even though real subrogation within separate patrimonies does not transfer rights per se, it seems to be doing more than tracing. It subjects new rights to substitutes to a certain framework of enforceability. Therefore, it is suggested tracing and real subrogation cannot be equated.

\section{Property in a fund and in a patrimony}

The question remains though whether one has a property right to the fund/patrimony or to the assets within it.

\section{A. Property in a patrimony as a collection of assets}

A group of assets held in the hands of a person gives rise to a question whether the person has a property right to the assets within the collection or whether the collection is itself a subject matter of a property right.

Roman law, under the influence of the stoic doctrine ${ }^{92}$, distinguished between things as singular, complex and collections. ${ }^{93}$ Singular things ${ }^{94}$, such as an

\footnotetext{
${ }^{89}$ Kitłowski (n23) 35.

90 L Smith, The Law of Tracing (Clarendon Press, Oxford 1997); Foskett v McKeown [2001] 1 AC 102, 128 (Millett LJ); contra eg C Rotherham, 'The Metaphysics of Tracing: Substituted Title and Property Rethoric' (1996) 34 Osgoode Hall LJ 321.

91 This may be more difficult in real subrogation outside of separate funds, see section above.

92 W Wołodkiewicz and M Zabłocka, Prawo Rzymskie (Roman Law) (CH Beck, Warszawa 2001) 120.

93 D 6,1,23,5; D 41,3,30.
} 
animal, a beam (tignum) or a stone, constituted a unity both legally and economically and as such were unproblematic for the questions of transfer of property. ${ }^{95}$ The difficulties arose with respect to complex or composite things. Complex things, or corpora ex cohaerentibus, referred to in mediaeval writings as universitas rerum cohaerentium, were things composed of a number of elements, joined in a lasting manner so that they became unified both legally and economically, e.g. a building or a ship. Once a beam (tignum iunctum) became a part of a building, it lost its independent character. The owner of a beam could not vindicate it ${ }^{96}$ although he could demand double its value. Collections, one the other hand, were different. Referred to in the Digest as corpora ex distantibus, and laballed later as universitas rerum distantium, collections were groups of things, each of which retained their physical character whilst existing as a one whole: e.g. libraries or herds of animals. The owner of a herd could vindicate both an entire herd (vindicatio gregis) or particular animals within it. ${ }^{97}$ The reason for allowing vindication of an entire collection in Roman law was clearly convenience in cases such as the transfer of testator's legacy. ${ }^{98}$ In other situations, however, the important unit was the individual animal, not the herd. ${ }^{99}$ It seems that a number of authors have later confounded the two types of universitas rerum with each other, thus blurring the crucial difference in the vindication method of each type. ${ }^{100}$ The distinctions drawn by the Romans may be of particular use when discussing the property in a fund.

Polish property law has not recognized the concept of universitas rerum. Unlike in the Roman law, universitas rerum is not a res. Selling a collection of books

\footnotetext{
${ }_{94}$ Referred to in later writings as res singulae although the Digest does call them by this name. See e.g. CK Allen, 'Things' (1940) 28 Cal L Rev 421, 429.

95 D 41,3,30 fine: usucapione quaestionem non habet". Usucapio is understood here broadly as relating to the issues of transfer of property, although it was more often associated with acquisition of property regardless of the owner's title, i.e. in the case of adverse possession. See e.g. , 'The Operation of Usucaption in Roman Law' (1920) 1 Law Coach 23; R Yaron, 'Reflections on Usucapio' (1967) 35 Tijdschrift voor Rechtsgeschiedenis 191.

${ }^{96}$ Established as early as XII Tables, Table 6,8 (an owner of a stolen beam was prevented from taking the beam out from a building, into which it had been incorporated).

97 D 41,3,30; J 2,20,18.

98 A Watson, Studies in Roman Private Law (1st edn Hambledon Continuum, 1990) 139. Note the permissive rather than declarative language of J 2,20,18: "vindicari potest", which seems to indicate perhaps that there were other ways of vindication (i.e. vindication of each individual element) that were the norm.

${ }^{99}$ See Ibid.139-140.

100 Allen (n94) 429; Gretton (n3) 615-616.
} 
requires transfer of property of each and every book within the library, ${ }^{101}$ unless the statute provides otherwise. ${ }^{102}$ Likewise, a universitas iuris, meaning a collection of rights, claims and sometimes also things, is not a res. Thus, a patrimony, an enterprise or a fund within an enterprise cannot be treated as legally distinct subject matter of property rights notwithstanding their economic (functional) integrity and notwithstanding their grouping (or segregation) for a specific purpose. ${ }^{103}$ Yet, they can be subject to contract and obligation relationships (including an obligation to transfer property) as ensemble. ${ }^{104}$ Property is, however, transferred separately to each asset. One can therefore never have a property right to a separate patrimony in civil law; merely to assets that fall within it.

Bearing in mind that the separate patrimonies evince a protection of assets from certain creditors, the position of $A$, who is entitled to assets ( $\left.a_{1} \ldots a_{n}\right)$ within patrimony separate from B's patrimony is the following. If A wants to transfer the property rights to $\left(a_{1} \ldots a_{n}\right)$ A must do so separately with respect to each asset. At no point can B's creditors seize assets $\left(a_{1} \ldots a_{n}\right)$. A's own creditors with respect to claims concerning $\left(a_{1} \ldots a_{n}\right)$ may or may not have access to $\left(a_{1} \ldots a_{n}\right)$.

\section{B. Property in a trust fund in English law}

If we are to draw functional parallels between the separate patrimony and the trust fund, the characterization of a separate patrimony as a sum of assets rather than a res sits uncomfortably with the view of a reified trust fund, proffered by James Penner.

Penner conceives of a fund as a distinct property interest, not merely as an interest in multiple items of property. ${ }^{105}$ Penner observes that the whole point of

\footnotetext{
101 J Ignatowicz and K Stefaniuk, Prawo Rzeczowe (2nd edn LexisNexis, Warszawa 2006) 20; Similarly - Dutch law, see L v Vliet, 'The Boundaries of Property Rights: Netherlands National Report 2006' (2007) 11 Electronic Journal of Comparative Law .

102 See e.g. art 257§1 of the Polish Civil Code (concerning usufructus); art 7(2)(3) of the Polish Law on Registered Charge and the Charge Register.

103 Ignatowicz and Stefaniuk 20; Dutch law is similar in this respect. See Vliet (n101) see also e.g. $\S 30$ I Abs 1 of the German Investmentgesetz: "Die zum Sondervermögen gehörenden

Vermögensgegenstände.."

104 E Gniewek, Prawo Rzeczowe (CH Beck, Warszawa 2003) 4-5.

105 J Penner, 'Duty and Liability in Respect of Funds' in J Lowry and L Mistelis (eds), Commercial Law: Perspectives and Practice (Lexis Nexis, Butterworths, London 2006) 12.16, p 212. See also McKendrick (ed) (n37) 45 and 65.
} 
a fund is that it facilitates the exchange of assets. ${ }^{106}$ Therefore, "an interest in a fund is an interest not only in the assets in it at the moment but in those assets to the extent they become realized via exchange“.107 Although the beneficiary has no interest in any assets presently comprising the fund, he has rights given under the terms of his interest in the fund. ${ }^{108}$ It is part of beneficiary's interest in fund to have an option of electing to accept or reject wrongful transactions of the trustee. On this analysis, tracing claims are simply an aspect of the beneficiary's property right in a fund.

Penner's conceptualisation of property in a fund has been met with an objection offered by Sheehan, ${ }^{109}$ who builds on Nolan and Fox's view of funds, to show that at no point can the beneficiary of a trust have an interest in a fund reified separately from assets within it. ${ }^{110}$ As Sheehan points out, the starting point is that a trustee holds specific assets for the benefit of the beneficiary, which he must keep safe and from which he may not derive any personal benefit. ${ }^{111}$ If the trustee is to invest trust property, as is usually the case, to generate a return for the beneficiaries, his investment powers will lead to existing assets being (from time to time) subsituted for new ones. The beneficiaries will then continu to have the same interest in teh new asset. For this to work, the trustee, as the fundholder, has a power to alienate the assets free from the fund-beneficiary rights (the overreaching power). ${ }^{112}$ The beneficiary acquires the same right in whatever asset the trustee acquires as a result of the exercise of the trustee's overreaching power, as he had in the asset before the exchange. Otherwise, the exercise of the trustee's power would lead every time to a new separate trust

\footnotetext{
106 J Penner, 'Value, Property and Unjust Enrichment: Trusts of Traceable Proceeds' in R Chambers, C Mitchell and J Penner (eds), Philosophical Foundations of the Law of Unjust Enrichment (OUP, Oxford 2009) 315: "the history of the fund is the history of the exchanges of its assets". It may be said that Penner views the fund as an "exchnage facilitator".

107 Ibid. 315.

108 Ibid. 314.

${ }^{109}$ D Sheehan, 'Property in a Fund, Tracing and Unjust Enrichment' (2010) 2 J of Eq 225.

110 Ibid.,226.

111 Ibid., 226; Pickering v Pickering (1839) 2 Beav 31.

112 Nolan (n 37) 108; R Nolan, 'Understanding the Limits of Equitable Property' (2006) 1 Journal of Equity 1820; D Fox, 'Overreaching' in P Birks and A Pretto (eds), Breach of Trust (Hart, Oxford 2002) 95-96.
} 
over a new asset.113 The beneficiary's interest may also expire without there being any replacement entering the trust fund. This takes place when the trustee (the manager) transfers an asset to a third party in an authorised way and receives nothing in return.

For as long as the trustee acts within his powers and the dispositions of trust property are authorised by the trust instrument, on Nolan's analysis, the right to claim substitute assets derives solely from the bargain or undertaking which establishes the beneficiaries' rights in the individual items of trust property. For Penner, the interest which the fund beneficiary has is not in the individual assets comprising the fund, the elements of which "may fluctuate because of the exercise of the powers of the fund manager",114 but rather "his interest is only in whatever rights are given under the terms of his interest in the fund".115 For Penner, when the trustee acts within his powers, the beneficiary's rights with respect to property are legally protected by the trustee's enforcement of his legal rights to the trust property and the beneficiary does not have any rights to enforce legal rights himself. ${ }^{116}$ Thus, for Penner, the beneficiary's interest falls short of proprietary, although the beneficiary can at any point be said to have a distinct kind of property interest in the fund itself.117 Whether the beneficiary's interest is proprietary is controversial and clearly depends on what makes a right proprietary. ${ }^{118}$ This question is not explored here. Suffice it to say that Nolan's view is that the beneficiaries' proprietary rights consist in their negative rights to exclude non-beneficiaries from the unencumbered enjoyment of trust property. ${ }^{119}$ This conceptualisation also works in the case of discretionary trusts,

113 C Rickett, 'Old and New in the Law of Tracing' in S Degeling and J Edelman (eds), Equity in Commercial Law (Lawbook Co, Sydney 2005), 136.

114 Penner (n105) 212 at 12.16.

115 Ibid. 212 at 12.16.

116 Ibid. 212, at 12.16 .

117 Ibid. 212, at 12.16; Penner, 'Value, Property and Unjust Enrichment: Trusts of Traceable Proceeds' 314.

118 Sheehan (n109) 232.

119 R Nolan, 'Equitable Property' (2006) 122 LQR 232, 236-238; see also K Gray, 'Property in Thin Air' (1991) CLJ 252, 292-295. 
and as Sheehan shows ${ }^{120}$, beneficiaries of a discretionary trust may also be said to have proprietary interest in the individual assets.

It seems worth pointing to a particular type of non-beneficiaries which the beneficiary has a negative right to exclude, namely the trustee's creditors. The segregation of the trust assets from trustee's other assets insofar as his creditors' claims are concerned, is explained by the proprietary right of the beneficiary to exclude these creditors from seizing and selling the trust assets. Notice that on this analysis of segregation, it is not relevant that the creditors of the trust sue the trustee in his own capacity. ${ }^{121}$

Before moving on to the discussion of rights of a beneficiary when a trust is breached, let us pause to sketch a parallel between rights of a common law trust beneficiary and rights of a patrimony owner.

\section{Convergence of the trust fund and separate patrimony ${ }^{122}$}

\section{A. Authorised dipositions: exercise of trustee's powers and real subrogation parallel}

For as long as a civilian patrimony is not a res but merely a collection of assets, which appears to have been the case in Roman law and is now the case, for instance, in Poland, no one has a property right to a civilian (separate) patrimony. Penner's trust fund view as a distinct property interest is divergent from the way the civilian separate patrimony has been understood.

For a separate patrimony to be comparable to a common law trust fund, two aspects must be considered: (1) segregation of the fund from the manager's assets, and (2) exchangeability of the assets within the fund. First, a separate patrimony is by its very nature, as discussed above, segregated from other assets

\footnotetext{
120 Sheehan, 231-234 and cases cited there: Federal Commissioner of Taxation $v$ Vegners (1989) 90 ALR 547, 552 (Gummow J); Chief Commissioner of Stamp Duties v Buckle (1998) 192 CLR 226, 234.

121 See Smith (n12) 18-19. The liabilities incurred by the trust fund are usually satisfied from the trustee's own funds. The trustee then will have a right of recourse against the trust assets but the creditors can enforce the claim against both the trust assets and trustee's own assets.

122 The idea of convergence is itself controversial in its principle, although this is not discussed here. See e.g. B Markesinis, 'Learning from Europe and Learning from Europe' in B Markesinis (ed) The Gradual Covergence (Clarendon Press, 1994) and his critic P Legrand, 'European Legal Systems Are Not Converging' (1996) 45 ICLQ 52.
} 
of the patrimony-holder/manager (A), so that A's creditors cannot seize the assets within the separate patrimony to satisfy their claims. Assuming that the common law trust beneficiaries can be said to have proprietary rights in individual assets, the effect of the beneficiaries' negative rights to exclude trustee's creditors is exactly the same.

The second aspect of the fund/patrimony is more complicated. The exchangeability of the assets within a trust fund is achieved by the exercise by the trustee of the power to make investments. The necessary corollary of powers in the trustee is overreaching, which means that a purchaser of property takes free from any interests or powers, which instead attach to the proceeds of sale. ${ }^{123}$ Exchangeability of assets is not inherent in the concept of a separate patrimony. If substitute assets are retained in the trust fund, it happens due to the exercise of powers of the trustee. Real subrogation operating within separate patrimonies renders a similar result. It allows for the asset to be protected from A's creditors' claims in the same way as the previous asset was. It does not, however, necessarily institute in the new asset an identical right. Nor does it imply that it cannot. Real subrogation within separate patrimonies ensures that the person entitled to the original asset within the separate patrimony will have the right to exclude certain creditors from claiming against the new asset inasmuch as they were excluded form claiming against the old asset. Yet, bearing in mind how both types of real subrogation operate, and that the effect of the exercise of the trustee powers is that the beneficiary has a the same right in the new asset, it is necessary to consider whether the model of real subrogation outside of separate funds would not be a better candidate for drawing parallels with the trust fund. If a beneficiary has a particular right against the asset in the trustee's hands then in order to ensure that the beneficiary has the same right in new asset, real subrogation operating in singularibus seems better cut-out to do the job. Clearly, our choice of real subrogation model depends on the right, which the beneficiary is thought to have in the trust asset. Assuming that the beneficiaries' proprietary rights consist in their negative rights to exclude nonbeneficiaries from the unencumbered enjoyment of trust property, in particular

\footnotetext{
${ }^{123}$ Fox (n112); Rickett (n113); Sheehan (n109).
} 
to exclude trustee's personal creditors from seizing trust assets, then the right in the new asset which appears upon the exercise of the trustee's overreaching power, will also be a right to exclude the trustee's creditors from seizing that property in execution. The effect of applying the real subrogation model within separte funds would have the same effect in this case as applying real subrogation outside of separate funds. We must recall, however, that real subrogation in singularibus is only allowed on the basis of a specific provision, which is not true for a real subrogation in pluralibus. If we were looking for a ready-to-use doctrine to apply in a civilian "trust", which would ensure that the "beneficiary" continues to have rights in proceeds of authorised disposition of the property originally settled on "trust", then real subrogation in universalibus would be a better candidate because it is likely that it could operate within a collection of assets perceived as a separate patrimony without a prior intervention from a legislator, at least where there is no explicit Surrogationsverbot. This has potential consequences for the extent to which a "trust-like" instruement could be used in civil law countries. The potential application of real subroagtion in pluralibus is subject to certain assumptions. First, as soon as the right of the beneficiary is perceived otherwise than as a right to exclude non-beneficiaries for the enjoyment of trust property, real subrogation in universalibus will struggle to provide the civil law "beneficiary" with a continuing right to a new asset. Second, we would need to ensure that real subrogation in universalibus overcomes its difficulties with multiple substitutions at least as well as real subrogation in singularibus. ${ }^{124}$ Therefore, even though real subrogation in singularibus is a better parallel to draw with the power of the trustee to dispose of the asset, under certain assumptions, real subrogation in universalibus may achieve the same results.

\section{B. Unauthorised dispositions by the trustee}

In unauthorised transactions the contract power of the manager of the trust fund does not exist. The right of the beneficiary to substitute cannot therefore derive from the bargain. Nolan's analysis does not explain this, nor does it claim to.

\footnotetext{
${ }^{124}$ See above section $2 \mathrm{~A}$.
} 
However, Nolan indicates that remedial interests over a fluctuating class of assets are constructs of law, the role of which is different from property in a fund $^{125}$. The latter is a product of a consensual stipulation whilst the former arise to fill the gaps beyond such a consenual ordering of affairs. ${ }^{126}$

To Penner, on the other hand, it is not until the trust is breached that the beneficiary's proprietary interest comes to light. ${ }^{127}$ Only then the beneficiary may elect to enforce a direct proprietary interest in individual items of the fund.In such a case the beneficiaries' claim to substitute assets is "part and parcel of the nature of the property interest that the beneficiairies have, that is an interest in a fund". ${ }^{128}$ Sheehan convincingly argues that "we can only identify a breach of trust obligation if we can identify the asset misused. Indeed we cannot identify a fund without identifying assets within it". ${ }^{129}$ Consequently, the view of a reified trust fund cannot explain claims of a beneficiary to traceable proceeds of a trustee's unauthorised dispositons.

The basis for claiming traceable proceeds of an unauthorised disposition, particularly in the hands of third parties, is a thorny issue. Much ink has been spilt in English law on arguing that the beneficiary's right arises to reverse the unjust enrichment ${ }^{130}$, or that it arises because of the law of property as vindication of existing rights ${ }^{131}$, or yet some other ${ }^{132}$ explanation of these claims.

\footnotetext{
125 Nolan (n37) 110 and 131.

126 Ibid., 131.

127 Penner (n105) 212, at 12.16.

128 Penner, (n117) 314.

129 Sheehan (n109), 231.

130 P Birks, Unjust Enrichment (2nd edn OUP, Oxford 2005) 35; P Birks, 'Receipt' in P Birks and A Pretto (eds), Breach of Trust (Hart Publishing, Oxford 2002) 216-222; P Birks, 'On Taking Seriously the Difference between Tracing and Claiming' (1997) 11 Trust Law International 2, 7-8; P Birks, 'Property and Unjust Enrichment: Categorical Truths' (1997) New Zeland Law Review 623, 661; P Birks, 'On Establishing a Proprietary Base' (1995) 3 RLR 83, 91-92; A Burrows, 'Proprietary Restitution: Unmasking Unjust Enrichment' (2001) 117 LQR 412; A Burrows, The Law of Restitution (2nd edn Butterworths, London 2002) 64; Smith, The Law of Tracing 300 but see L Smith, 'Restitution: The Heart of Corrective Justice' (2001) 79 Texas L Rev 2115 which represents a more nuanced approach leaning towards the vindication view.

131 G Virgo, The Principles of the Law of Restitution (2nd edn OUP, Oxford 2006) 11-17; Penner, 'Value, Property and Unjust Enrichment: Trusts of Traceable Proceeds' 313-314; J Penner, The Law of Trusts (OUP, Oxford 2008) at 2.32; 11.89-11.95; 11.116-11.123; Foskett v McKeown [2001] 1 AC 102; P Millett, 'Proprietary Restitution' in S Degeling and J Edelman (eds), Equity in Commercial Law (Lawbook Co, Sydney 2005) 314. See also L Smith, 'Unjust Enrichment, Property and the Structure of Trusts' (2000) 116 LQR 412, 413; L Smith, 'Transfers' in P Birks and A Pretto (eds), Breach of Trust (Hart Publishing, Oxford 2002) 121, fn 42.
} 
This paper is not a place to contribute to this debate but it is a right forum to consider how, if at all, real subrogation could operate in such cases.

Before progressing, a digression may be of interest here. Peter Birks drew a parallel between the vindication approach assumed in Foskett $v$ McKeown ${ }^{133}$ and real subrogation. ${ }^{134}$ Birks compared it to a fishing line which hooks onto different assets as they "swim" past. 135 To him it was a fiction that a beneficiary could assert the same property right in the substitute as the right in the original trust asset because it meant that the event from which the right in the substitute arose was the original declaration of express trust. ${ }^{136}$ The way Birks viewed real subrogation corresponds better to the way the doctrine operates outside of separate funds, although in such cases the right over new asset may turn out to be a new right ratehr than a continuing interest, as we have seen. ${ }^{137}$

In Polish law it is not clear whether a person entitled to a separate patrimony managed by another could claim that proceeds of an unauthorised disposition by the manager fall in the separate patrimony by means of real subrogation. As mentioned above, it is controversial, at least in Polish law, whether real subrogation can operate within separate patrimonies on the basis of an agreement of the parties or whether a legislative provision is needed every time. If real subrogation is based on a specific provision that any assets acquired with the means from a separate patrimony fall within that patrimony, the question whether or not the manager of the fund was authorised to do so becomes irrelevant. As long as the disposition involved assets from the separate patrimony, any proceeds of such a disposition would fall within the separate patrimony. Issues of mixed substitutions are not discussed here but, it is submitted, they are unlikely to change the principle that any substitutes acquired with the means from the separate patrimony would inhere in that patrimony.

\footnotetext{
${ }^{132}$ Such as wrong of misappropriation, or a wrongful interference; see S Worthington, 'Justifying Claims to Secondary Profits' in E Schrage (ed) Unjust Enrichment and the Law of Contract (Kluwer Law International, The Hague, London, New York 2001) 451, 455 (rejecting property and unjust enrichment analyses).

133 [2001] 1 AC 102.

134 Birks, Unjust Enrichment (n130) 35.

135 Ibid.35.

136 Ibid. 35.

137 Section 3 A (b).
} 
If we accept that real subrogation can also be agreed by the parties, unauthorised dispositions fall outside of the parties' bargain and the problem is analogous to that of the unauthorised trustee dispositions in English law: the property in the trust fund/separate patrimony is neither here nor there as far as explanation of claims to traceable proceeds of unauthorized transactions is concerned. It seems that in order to ensure that proceeds of such unauthorised dispositions are held by the manager, the parties would need to explicitly agree such a result. Otherwise the owner of assets within separate patrimony, which were disposed contrary to the bargain, would normally have a contractual claim against the manager. It is uncertain whether any proprietary claim (such as vindicatio), or contractual (such as unjust enrichment) would arise. The causes of action would, however, be independent from the separate patrimony or real subrogation.

It seems that the lack of ability to provide answer to unauthorised disposition claims by the concepts of separate patrimony and real subrogation is another point of functional similarity with the trust fund and the exercise of powers by the trustee. This correlation may well imply that there is a potential for convergence of the concepts of separate patrimony and real subrogation on one hand and trust fund and the exercise of trustee's powers on the other.

\section{Conclusions}

This paper suggests that a parallel between the trust and a civilian separate patrimony could be drawn without any insistence on a purpose fund. It has been argued that a trust can be understood in civil law terms as a separate patrimony. Neither the trust fund nor the separate patrimony are distinct property interests. The trust beneficiary and the person entitled to the separate patrimony have rights to individual assets within the fund or within patrimony. It has also been shown that parallels can be drawn with the way real subrogation operates in Polish law. In English law assets vary within a trust fund as a result of the exercise of trustee's powers of dispositions according to the trust instrument, whilst in Polish law this function is performed by real subrogation. The application of the doctrine cannot be viewed as an equivalent of tracing because tracing is merely an evidential process. Real subrogation either transfers rights, 
if outside of separate patrimonies, or it places rights to new assets within a particular framework of enforceability of separate patrimonies. Functional parallels can be drawn between the trustee's exercise of powers with both types of real subrogation although it is the real subrogation in singularibus that better reflects structurally the exercise of powers by the trustee. When the trustee misappropriates a trust asset, he acts outside of the authority granted by the trust instrument and neither real subrogation nor the exercise of powers by teh trustee can explain the rights, which the beneficiary might have against the third party.

It also follows that a mere existence of a separate patrimony, even with a mechanism ensuring that exchangeability of assets takes place, such as the German mutual fund built on Treuhand, is not sufficient to say that the beneficiary of such an arrangement has a proprietary right. Just as in English law, the lawyers operating in civilian systems with "trust-like" tools must find a different way of explaining the nature of the beneficiary's interest, not with reference to the trust fund or the separate patrimony. 